\title{
ENGLISH, GERMAN AND FRENCH LOANWORDS IN UZBEK LANGUAGE
}

\author{
Ziyoda Baxtiyorjon Qizi Abdurazzoqova
}

Second Year Master Student, Fergana State University, Uzbekistan

\section{ABSTRACT}

It is possible that each small change can make great importance in our modern life. Like this, loanwords which we never pay attention in usual conversations are also regarded as significant units the subject of linguistics. Mainly, the process of borrowing them is special theme, having many strategies and ways and generally they are called as a adaptation. Such kind of adaptations are noted in Uzbek language also and these are so much efficient for professional language learners.

KEYWORDS: - Loan words, calque, language, meaning, idiom, pattern, vocabulary, changes, borrowings.

\section{INTRODUCTION}

The age in which we are living demands changes and news not for every day, but every minutes. Language also not exception of these processes. Each language change or enrich with help of loanwords. Many researches on the theme of loanword nativization has been carried on with the terms of a 'Coreperiphery' organization of the lexicon[1]. Such kind of procedure can be also seen in Uzbek language. However, initially, we must understand what is loanwords. According to Yoonjung Kang's point of view "loanwords are words that are borrowed from one language to another language"[2] this linguistic concept occurs among two or more than two languages whenever one language effects to another language. It means, for example, first language has a word, but second language does not have a word that can explain the word in the first language, in this situation the second language takes the word to define the new meaning. Because of having special rules of each language, "loanwords must be adapted to fit the second language`s speech patterns" [3] the adaptation encircles many branches of linguistics and now phonology side of adaptation is chosen to analyze.

\section{Literature review}

The literature that used in this article explain the procedure of adaptation of loanwords with the examples of different languages. In "Loanword phonology" by Yoongjung Kang, the process of how a word become a loanword from one language to another language is defined deeply. The next book "Loan phonology" is the collection of articles which explain loans in many languages, in instance, "The 
CURRENT RESEARCH JOURNAL OF PHILOLOGICAL SCIENCES 2(11):

146-149, November 2021

DOI: https://doi.org/10.37547/philological-crjps-02-11-31

ISSN 2767-3758

(C)2021 Master Journals

Crossref do

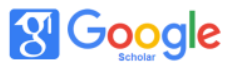

Accepted25th November, 2021 \& Published 30 ${ }^{\text {th }}$ November, 2021

adaptation of Romanian loanwords from Turkish and French", " Mandarin adaptations of coda nasals of English loanwords" etc.. The book "German loanwords in Uzbek language" written by O.Jumaniyozov is about the features of adaptation of loanwords from German to Uzbek languages. Kevin Michael McCarty show adaptation according to the phonological, morphological and semantic points of view[4].

All these works, which mentioned above, are efficient to understand the meaning of loanwords and its adaptation in examples of many languages, supporting learners of linguistics. Used literature in this article are related to mainly the words are borrowed from or to English language and adaptive effects to each language.

\section{RESEARCH METHODOLOGY}

In this article, loanwords and the prosedure of borrowing them from a language to languages is diskussed as a main theme. Additionally, some examples are given in order to make the theme more understandable and clear for readers. Used literature in this article are related to mainly the words are borrowed from or to English language and adaptive effects to each language. Utilizing these materials, we will try to demonstrate phonology of loanword in Uzbek language that are borrowed from English, German and French. The study of the origin of these words and theirfunction and context within the language can illuminate some important aspects andcharacteristics of the language, and it can reveal insights on the phenomenon of lexicalborrowing in linguistics as a method of enriching a language.

\section{AnAlysis AND RESUlts}

A loanword is distinguished from a calque (or loan translation), which is a word or phrase whose meaning or idiom is adopted from another language by word-for-word translation into existingwords or word-forming roots of the recipient language. [5]Examples of loanwords in the English language include café (from French café, which means"coffee"), bazaar (from Persian bāzār, which means "market"), and kindergarten (from GermanKindergarten, which literally means "children's garden").The word calque is a loanword from the French noun calque ("tracing; imitation; close copy"): while the word loanword and the phrase loan translation are calques of the German nounsLehnwort and Lehnübersetzung[6].. Loans of multi-word phrases, such as the English use of the French term déjà vu, are known asadoptions, adaptations, or lexical borrowings. The terms substrate and superstrate are often used when two languages interact[7].. However, themeaning of these terms is reasonably well-defined only in second language acquisition orlanguage replacement events, when the native speakers of a certain source language (thesubstrate) are somehow compelled to abandon it for another target language (thesuperstrate)[8]..

Most of the technical vocabulary of classical music (such as concerto, allegro, tempo, aria, opera, and soprano) is borrowed from Italian, and that of ballet from French. Resembling English, the basa of uzbek language also was enlarged with such kind of words. For instance, "gitara", "pionina" or "royal" and etc.

Much of the terminology of the sport of fencing also comes from French.Many loanwords come from prepared food, drink, fruits, vegetables, seafood and more fromlanguages around the world. In particular, many come from Italian cuisine (e.g. pasta, linguine,espresso), French (soufflé, crêpe, crème brûlée), and Chinese (dim sum, chow mein, wonton).From food and drinkLinguistic classification. 
CURRENT RESEARCH JOURNAL OF PHILOLOGICAL SCIENCES 2(11):

146-149, November 2021

DOI: https://doi.org/10.37547/philological-crjps-02-11-31

ISSN 2767-3758

(C)2021 Master Journals

Crossref do

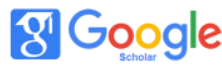

Accepted25 $5^{\text {th }}$ November, 2021 \& Published 30th November, 2021

The studies by Werner Betz (1971, 1901), Einar Haugen (1958, also 1956), and Uriel Weinreich(1963) are regarded as the classical theoretical works on loan influence[9].. The basic theoreticalstatements all take Betz's nomenclature as their starting point. Duckworth (1977) enlargesBetz's scheme by the type "partial substitution" and supplements the system with English terms.A schematic illustration of these classifications is given below.[10]The phrase "foreign word" used in the image below is a mistranslation of the German Fremdwort,which refers to loanwords whose pronunciation, spelling, inflection or gender have not been adapted to the new language such that they no longer seem foreign. Such a separation of loanwords into two distinct categories is not used by linguists in English in talking about any language[11].. Basing such a separation mainly on spelling is (or, in fact, was) not common exceptamongst German linguists, and only when talking about German and sometimes other languagesthat tend to adapt foreign spellings, which is rare in English unless the word has been widely used for a long time. According to the linguist Suzanne Kemmer[12]., the expression "foreign word" can be defined as follows in English: "[W] hen most speakers do not know the word and if they hear it think it is fromanother language, the word can be called a foreign word. There are many foreign words andphrases used in English such as bon vivant (French), mutatis mutandis (Latin), and Schadenfreude(German).[13] This is however not how the term is (incorrectly) used in this illustration. On the basis of an importationsubstitution distinction, Haugen (1950: 214f.) distinguishes threebasic groups of borrowings: " Loanwords show morphemic importation without substitution.... Loanblends show morphemic substitution as well as importation.... Loanshifts showmorphemic substitution without importation". Haugen later refined (1956) his model in a review ofGneuss's (1955) book on Old English loan coinages, whose classification, in turn, is the one
byBetz (1949) again.Weinreich (1953: 47ff.) differentiates between two mechanisms of lexical interference, namelythose initiated by simple words and those initiated by compound words and phrases. Weinreich(1953: 47) defines simple words "from the point of view of the bilinguals who perform the transfer, rather than that of the descriptive linguist[14].. Accordingly, the category 'simple' words alsoincludes compounds that are transferred in unanalysed form". After this general classification,Weinreich then resorts to Betz's (1949) terminology.

According to Hans Henrich Hock and Brian Joseph, "languages and dialects ... do not exist in avacuum": there is always linguistic contact between groups.[15] The contact influences whatloanwords are integrated into the lexicon and which certain words are chosen over others.In some cases, the original meaning shifts considerably through unexpected logical leaps. TheEnglish word Viking became Japanese バイキング (baikingu), meaning "buffet", because the firstrestaurant in Japan to offer buffet-style meals, inspired by the Nordic smörgåsbord, was openedin 1958 by the Imperial Hotel under the name "Viking".[29] The German word Kachel, meaning "tile",became the Dutch word kachel meaning "stove", as a shortening of kacheloven, from GermanKachelofen, a cocklestove.

\section{Conclusion}

To conclude, the adaptation of loanwords has great role in the developments of languages. In this article phonological points mentioned. Because loanword phonology is regarded as a study of how non-native words are adapted to conform to the segmental, phonotactic, suprasegmental and morphophonological restrictions of borrower language[10]. It means, loanwords can encircle all spheres of linguistics. Phonology is the most important for borrowing words as it impacts to 
CURRENT RESEARCH JOURNAL OF PHILOLOGICAL SCIENCES 2(11):

146-149, November 2021

DOI: https://doi.org/10.37547/philological-crjps-02-11-31

ISSN 2767-3758

(C)2021 Master Journals

Crossref do

81 Google

Accepted $25^{\text {th }}$ November, 2021 \& Published $30^{\text {th }}$ November, 2021

each loanwords spelling system. It is noticeable that loanwords phonology also surrounds so many rules which are separated according to special peculiarities of each language.

\section{REFERENCES}

1. Friesner. L. M. (2009) The adaptation of Romanian loanwords from Turkish and French. John Benjamins publishing company: Amsterdam.

2. Yoongjung. K. (2013) loanword phonology. Oxford: Wiley-Blackwell.

3. Beel. R., Felder. J. (2013) Phonological adaptations of English loanwords in Turkish. High point university, USA: High point.

4. MxCarthy. K. M. (1969) the linguistic adaptation of loanwords in modern standard Turkish. Chapel Hill.

5. Celebrease. A. (2009) Perception, production and acoustic inputs in loanword phonology. John Benjamins publishing company: Amsterdam.

6. Best, Karl-Heinz, Kelih, Emmerich (eds.) (2014): Entlehnungen und Fremdwörter: QuantitativeAspekte. Lüdenscheid: RAMVerlag.

7. Betz, Werner (1949): Deutsch und Lateinisch: Die Lehnbildungen der althochdeutschenBenediktinerregel. Bonn: Bouvier.

8. Betz, Werner (1959): "Lehnwörter und Lehnprägungen im Vor- und Frühdeutschen". In: Maurer,Friedrich / Stroh, Friedrich (eds.): Deutsche Wortgeschichte. 2nd ed. Berlin: Schmidt, vol. 1, 127-147.

9. Bloom, Dan (2010): "What's That Pho?". French Loan Words in Vietnam Today; Taipei Times, [1](http://taipeitimes.com/News/feat/archive s/2010/05/29/2003474148).

10. Cannon, Garland (1999): "Problems in studying loans", Proceedings of the annual meeting of
theBerkeley Linguistics Society 25, 326-336.

11. Duckworth, David (1977): "Zur terminologischen und systematischen Grundlage der Forschungauf dem Gebiet der englisch-deutschen Interferenz: Kritische Übersicht und neuer Vorschlag".In: Kolb, Herbert / Lauffer, Hartmut (eds.) (1977): Sprachliche Interferenz: Festschrift fürWerner Betz zum 65. Geburtstag. Tübingen: Niemeyer, p. 36-56.Gneuss,

12. Helmut (1955): Lehnbildungen und Lehnbedeutungen im Altenglischen. Berlin: Schmidt.

13. Grzega, Joachim (2003): "Borrowing as a WordFinding Process in Cognitive HistoricalOnomasiology" (http://www1.kueichstaett.de/SLF/EngluVglSW/grzega1032.pdf ) ,Onomasiology Online (http://www.onomasiology.de) 4, 22-42.

14. Grzega, Joachim (2004): Bezeichnungswandel: Wie, Warum, Wozu? Heidelberg: Winter.

15. Haugen, Einar (1950): "The analysis of linguistic borrowing". Language 26, 210-231. 